\title{
GROWTH RATE, SPATIAL-TEMPORAL VARIATION AND PREVALENCE OF THE ENCRUSTING CYANOSPONGE (Terpios hoshinota) IN SERIBU ISLANDS, JAKARTA
}

\section{TINGKAT PERTUMBUHAN, VARIASI, SPASIO-TEMPORAL DAN PREVALENSI CYANOSPONG BERKERAK (Terpios hoshinota) DI KEPULAUAN SERIBU, JAKARTA}

\author{
Muhammad A. Nugraha ${ }^{1}$, Neviaty P. Zamani ${ }^{2}$, \& Hawis H. Madduppa ${ }^{2}$ \\ ${ }^{1}$ Study program Marine Science and Technology, Faculty of Fisheries and Marine Sciences- \\ IPB University, Bogor, 16680, Indonesia \\ ${ }^{2}$ Department of Marine Science and Technology, Faculty of Fisheries and Marine Sciences- \\ IPB University, Bogor, 16680, Indonesia \\ *E-mail: muhammadandrenugraha@gmail.com
}

\begin{abstract}
Terpios hoshinota is a cyanosponge encrusted on the substrate in coral reefs that may cause mass mortality on the infested corals. This research was conducted to investigate the magnitude of damage level of corals due to the T. hoshinota outbreaks by assessing its growth rate, spatiotemporal variation, and prevalence between two sites in Seribu Islands. Four-time observation (T0-T3) in over 18 months (2016-2017) was conducted to see the growth level of sponge using a permanently quadratic photo transect method of $5 \times 5 \mathrm{~m}\left(250.000 \mathrm{~cm}^{2}\right)$. The total coverage area of sponge on study site in the T0 was $65.252 \mathrm{~cm}^{2}$ and becomes $81.066 \mathrm{~cm}^{2}$ in T3. The highest level occurred on T2 of $2.051 \mathrm{~cm}^{2} /$ months in Dapur Island (the closest to Jakarta) and $483 \mathrm{~cm}^{2} /$ months in the Belanda Island (the further site). The highest sponge growth rate occurred on T1-T2 during transitional season from rainy to dry. The lowest growth rate was observed on T3 during transitional season from dry to rainy. In general, prevalence percentage was higher in Belanda Island than in Dapur Island. This study showed a persistence invasion of encrusting $\mathrm{T}$. hoshinota on coral reef ecosystem that may overcome the function and role of associated organisms.
\end{abstract}

Keywords: coral mortality, cyanosponge, invasive, seasonal variation

\begin{abstract}
ABSTRAK
Terpios hoshinota adalah cyanosponge bertatahkan pada substrat di terumbu karang yang dapat menyebabkan kematian massal pada karang yang terpapar. Penelitian ini dilakukan untuk menyelidiki besarnya tingkat kerusakan karang akibat wabah T. hoshinota dengan menilai tingkat pertumbuhan, variasi spasial, dan prevalensi antara dua lokasi di Kepulauan Seribu. Pengamatan empat kali (T0T3) selama lebih dari 18 bulan (2016-2017) dilakukan untuk melihat tingkat pertumbuhan spons menggunakan metode transek foto kuadrat permanen $5 \times 5 \mathrm{~m}\left(250,000 \mathrm{~cm}^{2}\right)$. Total cakupan area spons di lokasi penelitian di TO adalah $65,252 \mathrm{~cm}^{2}$ dan menjadi $81,066 \mathrm{~cm}^{2}$ di T3. Level tertinggi terjadi pada T2 2,051 $\mathrm{cm}^{2} /$ bulan di Pulau Dapur (terdekat dengan Jakarta) dan $483 \mathrm{~cm}^{2} / \mathrm{bulan}$ di Pulau Belanda (situs selanjutnya). Tingkat pertumbuhan spons tertinggi terjadi pada T1 -T2 selama musim transisi dari hujan ke kering. Tingkat pertumbuhan terendah diamati pada T3 selama musim transisi dari kering ke hujan. Secara umum, persentase prevalensi lebih tinggi di Pulau Belanda daripada di Pulau Dapur. Penelitian ini menunjukkan invasi persisten dari T. hoshinota pada ekosistem terumbu karang yang dapat mengatasi fungsi dan peran organisme terkait.
\end{abstract}

Kata Kunci: cyanosponge, invasif, kematian karang, variasi musiman

\section{INTRODUCTION}

A series of threats on coral reefs are responsible for broad damage, including coral bleaching, coral diseases, coral predator, and invasive species (Shi et al., 2012; Subhan et al., 2011; Wilkinson, 2004). The status of Indonesian coral reefs in 2019 
was categorized as very good with only 74 reefs $(6.42 \%)$ and 390 reefs $(33.82 \%)$ classified as poor out of 1153 reefs. (Hadi et $a l ., 2020)$. Some of the major threats on coral reefs are the epidemic coral diseases, invasive species, and human pressures (Wilkinson, 2008). Coral reefs damages are able to be caused by two factors namely abiotic (e.g. stress, temperature, sedimentation, un-stable nutrients of chemical materials, and ultra-violet radiation) and biotic factors (e.g. predation, competition with algae, infecting by diseases) (Subhan $e t$ al., 2014; Subhan et al., 2011; Johan, 2010). The coral reefs can be categorized as a healthy ecosystem when its living corals are higher than its abiotic components, a low threat level from other biotas that are recognized as competitors for coral reefs.

The competition of spaces to living and growing in the coral reefs ecosystem also become a threat for a broad coral cover and commonly activity discovering in the ecosystem. The existence of competitors for substrates in terms of life and growth is able to be said as a form of ecological process which is also affected by percent cover from each individual and community group happening naturally. The marine sponge is an integral part of coral reefs and is regarded as a strong competitor of space (Raj et al., 2018; Rossi et al., 2015; Diaz et al., 2001). Some sponges compete with stony corals for space through directly and indirectly contacts and releasing an allelopathic compound that is able to kill the coral tissues and significantly decreasing the photosynthesis potency of symbiotic zooxanthellae (Fonnegra et al., 2008; Pawlik et al., 2007; Porter \& Targett, 1988). One of several recognized sponges as benthos biota or sessile organism causing living corals decreasing is $T$. hoshinota. This sponge species is a plague that can drop the living coral cover significantly in Indo-Pacific coral reefs that are commonly happened during several decades (Wang et al., 2015). The black sponge covering coral reefs is a thin layer with less than $1 \mathrm{~mm}$ thickness is free of epibionts. Commonly in black or dark brown color, while individuals in the shallow habitat often are in greyish color due to having some calcium grains on the sponge' surface (Hirose \& Murakami, 2011; Yamaguchi, 1986). The process of killing coral reefs is executed by blocking off the body or surface of coral reefs which inhibits the photosynthesis of the coral reefs. Furthermore, T. hoshinata also can be transformed from a thin sheet-like encrusting and also uses tissues like small strings or fine tendrils to move to another place and continue a new normal life in the new place (Soong et al., 2009).

The Seribu Islands are composed of many small chained islands scratching off north Jakarta and has tropical coral reefs ecosystems in each island with the various condition and depends on the environment surrounding it from Jakarta Bay to the north. The first report on the emergence of $T$. hoshinota sponges in the Indonesian region by growing too large on the Seribu Islands, Java, and having examined the spicula through the COI mitochondrial DNA sequence affirming this specimen identity as T. hoshinota (de Voogd et al., 2013). It seems that this sponge is still growing steadily for 4 years and has reaffirmed the sequential morphological characteristics of COI DNA mitochondria located on the Dapur Island (Utami et al., 2018 Madduppa et al., 2017). Kayu Angin Bira, Belanda and Pramuka Seribu Islands (Madduppa et al., 2017). This study aims to see the ability of black sponge killer hard rock T. hoshinota to master the basic substrate in the coral reef ecosystem of Dapur Island and the Belanda Island of the Seribu Islands region, Jakarta.

\section{RESEARCH METHODS}

\subsection{Study Sites}

This research was conducted in four times over 18 months of data collection between $2016(\mathrm{~T} 0=$ March, $\mathrm{T} 1=$ June, and 
$\mathrm{T} 2=$ October) and 2017 (T3= August) in Dapur Island and Belanda Island. Dapur Island is characterized by the physical land condition of this small island has been submerged due to the abrasion process and only left the fringing reefs. There are four islands lost due to abrasion, including the Dapur island since 1970 based on the Governor's Decree of 2000 from a total of 115 islands to 109 (Sutanto, 2014). For the location of the Belanda Island is located in the core zone of Thousand Islands National Park. Is an absolute protection zone for the sake of plasma preservation in the form of habitat development, the Belanda island is included in the core III zone as protection of coral reef ecosystems. (Mujiyani et al., 2001). Following is the location of $T$. hoshinota coral killer sponge observations (Figure 1).

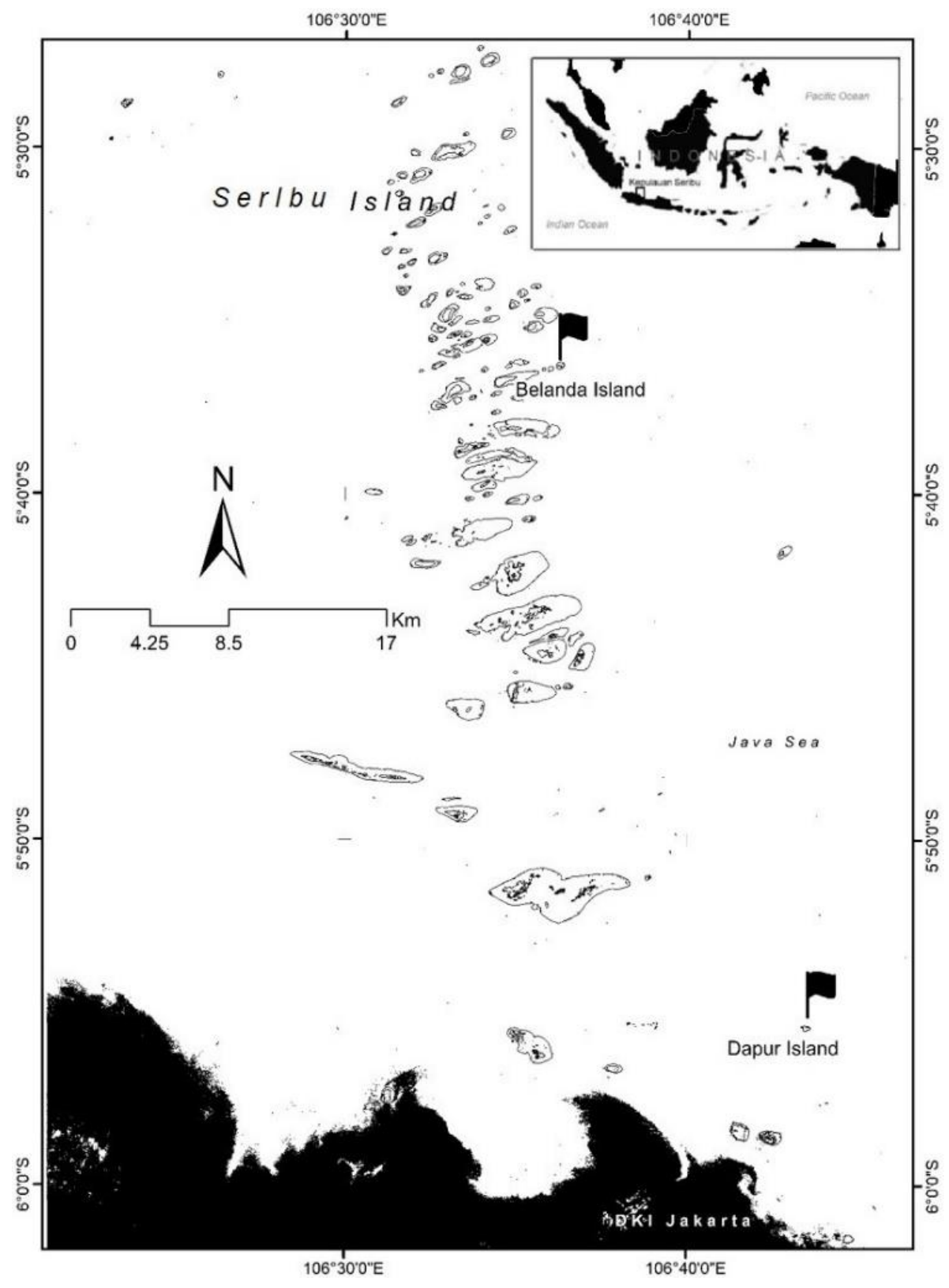

Figure 1. The study sites of killing corals sponge T. hoshinota outbreak in Thousand Islands, Jakarta. Closest to Jakarta Bay is Dapur Island, and the farthest is Belanda Island (the core zone of Seribu Islands Marine National Park). 


\subsection{Data Collection}

The data collection was set as many as four times in different months: March 2016 (T0), June 2016 with code T1, October 2016 with (T2), and August 2017 with the code T3. Coral Reefs Condition in the Surrounding Areas of $T$. hoshinota Outbreaks were observed using 2 replicates of $25 \mathrm{~m}$ long Line Intercept Transect (LIT) (English et al., 1997). with the UPT method (Underwater Foto Transect) (Giyanto, 2013).

Growth rate, growth area coverage, and prevalence of sponge $T$. hoshinota was observed by setting a permanently quadratic transect of $5 \times 5 \mathrm{~m}\left(250.000 \mathrm{~cm}^{2}\right)$. In this transect, a total of 25 small quadratic transects with a size of $1 \times 1 \mathrm{~m}$ were set and then photographed sequentially for analysis in the same way and at the same place at different times.

\subsection{Data Analysis}

The measurement of coral reef condition was carried out using a line incept transect (LIT) to acquire the coral reef percent cover referring to English et al. (1997) and to assess the standard of living coral reefs based on the Zamani \& Madduppa (2011). Analyzing the mortality index was referred to Gomez et al. (1994) and Edinger et al. (1998). Images from quadrat transect were further analyzed to quantified growth rate, a growth area, and prevalence by using Image-J software, Javabased software is able to analyze the size, the value of pixels and particles in digital images to get the level of accuracy of the area measured by a square centimeter. The prevalence data processing was based on the gained sponge distribution referred to the formula of Raymundo et al. (2008), Prevalence is the proportion of coral colonies infected or exposed to black sponge outbreaks of the total coral species found in each survey. Data analysis was presented using graphs and tables from Microsoft Excel simple software.

\section{RESULTS AND DISCUSSION}

\subsection{Results}

\subsubsection{Coral Reefs Condition in the} Surrounding Areas of $T$. hoshinota Outbreaks

The average percentage of live coral cover on Dapur Island was observed to be lower (19.04\%) than that of the Belanda Island $(23.56 \%)$, where the criteria of both islands were categorized as being in poor condition. The highest percent of Abiotics consisting of sand, rubble, silt, and rock in the Belanda Island (67.38\%) and Dapur Island $(55.75 \%)$ with the category of cover are both sufficient. The highest average of algae cover was in Dapur Island $(7.43 \%)$ from the Dutch Island (2.18\%) with the category of cover on both islands classified as very good. and percent of the mortality index (MI) in Dapur Island was observed to be higher $(0.7 \%)$ which indicates that there was a significant change from live corals to dead corals more than in the Belanda Island $(0.6 \%)$ (Table 1$)$.

The black sponges was observed on all hard substrates. A total of seven life forms and six genera were overgrown by black sponges at the study site (Table 2). Dapur Island has 4 genera and 6 coral life forms meanwhile in Belanda Island has 4 coral genera and 5 coral life forms. This condition is caused by the criteria of each location for the structure of the ecosystem of its coral habitat, the location of Dapur Island tends to have large and unbranched coral species, while the location of the Dutch island is more dominated by branching corals. (Figure 2).

\subsubsection{Growth Rate of Sponge \\ T. hoshinota}

Dapur Island, was observed a significant increase of the Sponge $T$. hoshinota growth during three times of observational period. The growth rate in Dapur Island ranged from June 2016 (T1) to October 2016 (T2), while in Belanda area 
Table 1. Percentage value of the coral reef condition between two islands over time. Live Coral (hard coral Acropora and non-Acropora). Dead Coral (dead coral and dead coral with algae). Abiotik (sand, rubble, silt and rock). Other Biota (soft coral, sponge, zoanthid, other biotas and unidentified). Algae Cover (macro algae, turf algae, coralline algae, halimeda and algae assembling). MI (Mortality Index).

\begin{tabular}{|c|c|c|c|c|c|c|c|}
\hline Location & Time & $\begin{array}{c}(\%) \\
\text { Live Coral }\end{array}$ & $\begin{array}{c}(\%) \\
\text { Dead } \\
\text { Coral }\end{array}$ & $\begin{array}{c}(\%) \\
\text { Abiotic }\end{array}$ & $\begin{array}{l}(\%) \\
\text { Other } \\
\text { Biota }\end{array}$ & $\begin{array}{c}(\%) \\
\text { Algae } \\
\text { Cover }\end{array}$ & $\begin{array}{l}(\%) \\
\text { MI }\end{array}$ \\
\hline Dapur & Mar/2016 & 10.01 & 3.02 & 60.05 & 16.42 & 10.50 & 0.8 \\
\hline \multirow[t]{3}{*}{ Island } & Jun/2016 & 23.50 & 0.70 & 50.66 & 16.76 & 8.38 & 0.6 \\
\hline & Oct/2016 & 16.20 & 2.84 & 62.05 & 10.50 & 8.41 & 0.7 \\
\hline & Aug/2017 & 26.46 & 1.56 & 50.22 & 19.35 & 2.42 & 0.6 \\
\hline \multirow{2}{*}{\multicolumn{2}{|c|}{$\begin{array}{l}\text { Average } \\
\text { Standard deviation }\end{array}$}} & 19.04 & 2.03 & 55.75 & 15.76 & 7.43 & 0.7 \\
\hline & & 7.40 & 1.10 & 6.18 & 3.74 & 3.48 & 0.1 \\
\hline Belanda & Mar/2016 & 20.14 & 2.36 & 67.48 & 6.00 & 4.02 & 0.7 \\
\hline \multirow[t]{3}{*}{ Island } & Jun/2016 & 21.52 & 6.30 & 67.36 & 1.20 & 3.62 & 0.6 \\
\hline & Oct/2016 & 25.76 & 4.26 & 68.28 & 1.34 & 0.36 & 0.7 \\
\hline & Aug/2017 & 26.80 & 4.48 & 66.40 & 1.60 & 0.72 & 0.4 \\
\hline \multirow{2}{*}{\multicolumn{2}{|c|}{$\begin{array}{l}\text { Average } \\
\text { Standard deviation }\end{array}$}} & 23.56 & 4.35 & 67.38 & 2.54 & 2.18 & 0.6 \\
\hline & & 3.22 & 1.61 & 0.77 & 2.32 & 1.91 & 0.1 \\
\hline
\end{tabular}

Table 2. The overgrown living coral and abiotic (solid substrate and rubble) by the sponge $T$. hoshinota at each island.

\begin{tabular}{llcc}
\hline \multicolumn{1}{c}{ Composition of life form (Genera) } & Dapur Island & Belanda Island \\
\hline Living coral: & ACB (Acropora) & + & + \\
ACT (Acropora) & - & + \\
CM (Lobophyllia) & - & + \\
CM (Porites) & + & - \\
CB (Pocillopora) & - & + \\
CB (Seriatopora) & + & - \\
CF (Porites) & + & + \\
& CSM (Porites) & + & - \\
\hline CMR (Fungia) & + & + \\
\hline Abiotic: & Solid Substrate non-coral & + & + \\
& Rubble & + & + \\
\hline
\end{tabular}

$+=$ overgrown present

$-=$ absent.

ranged from October 2016 (T2) to August 2017 (T3), which is represented by observation transect 2 . In general, this black sponge outbreak has symptoms of growth that occur between entering the dry season and at the end of the dry season, the peak of the rainy season occurs in January and the peak of the dry season is in August.

\subsubsection{Spatial and Temporal Variation of Sponge T. hoshinota}

Spatially, Dapur Island in the south showed a massive overgrown coral substratum by $T$. hoshinota in a total of $72.573 \mathrm{~cm}^{2}$ compared with Belanda Island covered in a total of $8493 \mathrm{~cm}^{2}$ after 18 months of observation. The width of this 


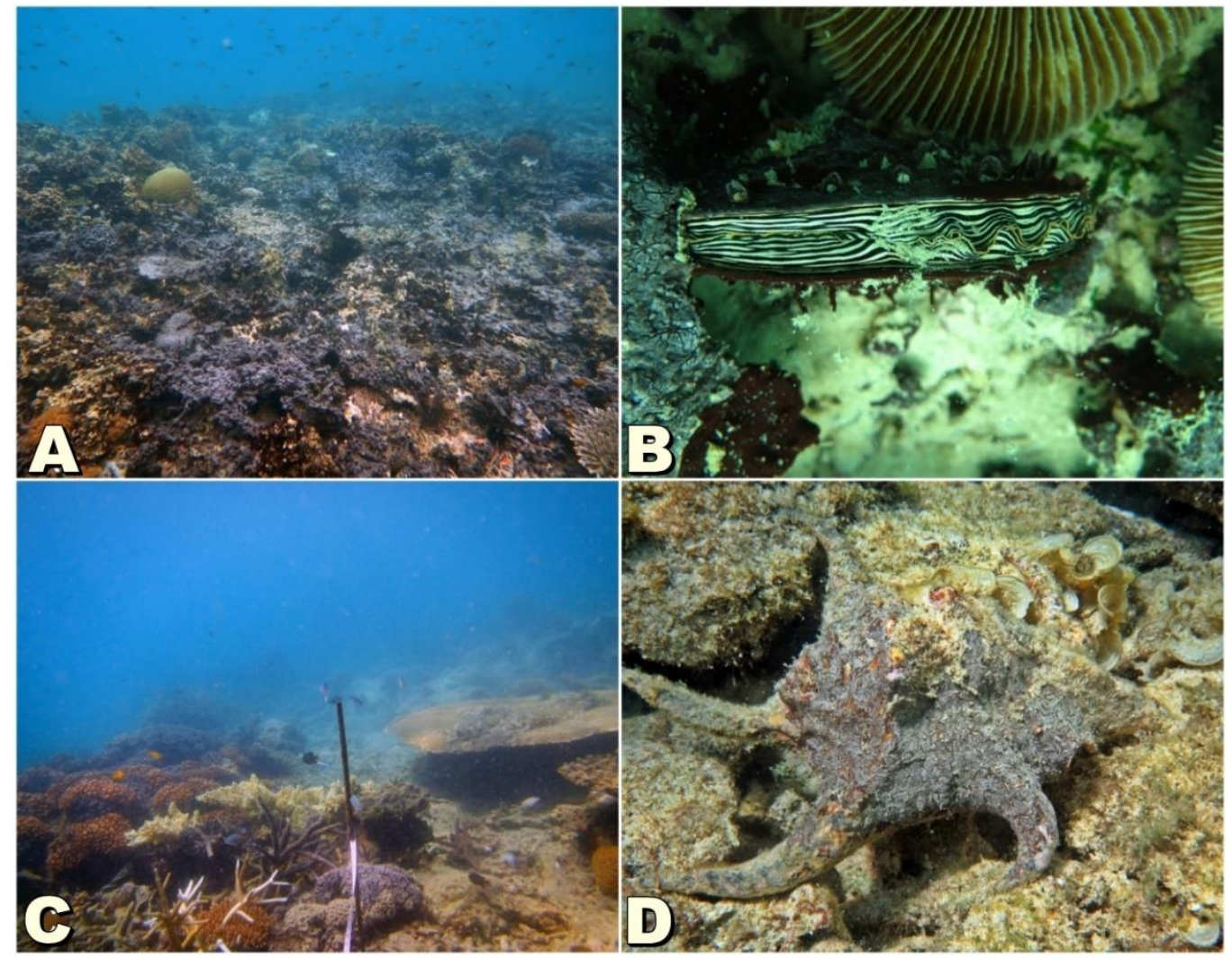

Figure 2. The condition of bottom cover in research location at Dapur Island (A), marine biota exposed by the sponge T. hoshinota in Dapur Island (B), the condition of bottom cover in research location at Belanda Island $(\mathrm{C})$, the marine biota exposed by the sponge T. hoshinota in Belanda Island (D).

Table 3. Spatial and temporal variation of growth rate $\left(\mathrm{cm}^{2} / \mathrm{month}\right)$, growth area $\left(\mathrm{cm}^{2}\right)$ and Total area of cover $\left(\mathrm{cm}^{2}\right)$ of the sponge T. hoshinota in the coral reef ecosystem between Dapur Island and Belanda Island over 18 months (2016-2017) covering rainy and dry season.

\begin{tabular}{lcclccc}
\hline Location & Transect & Time & Month/Season & $\begin{array}{c}\text { Growth rate } \\
\left(\mathrm{cm}^{2} / \text { month }\right)\end{array}$ & $\begin{array}{c}\text { Growth } \\
\text { area }\left(\mathrm{cm}^{2}\right)\end{array}$ & $\begin{array}{c}\text { Total area } \\
\text { of cover } \\
\left(\mathrm{cm}^{2}\right)\end{array}$ \\
\hline Dapur & 1 & $\mathrm{~T} 0 / 2016$ & Mar (rainy to dry) & - & - & 49.076 \\
Island & & $\mathrm{T} 1 / 2016$ & Jun (rainy to dry) & 1.207 & 3.621 & 52.697 \\
& & $\mathrm{~T} 2 / 2016$ & Oct (dry to rainy) & 1.641 & 6.564 & 59.261 \\
& $\mathrm{~T} 3 / 2017$ & Aug (dry) & 395 & 3.947 & 63.207 \\
\cline { 3 - 7 } & $\mathrm{T} 0 / 2016$ & Mar (rainy to dry) & - & - & 4.953 \\
& $\mathrm{~T} 1 / 2016$ & Jun (rainy to dry) & 594 & 1.783 & 6.736 \\
& $\mathrm{~T} 2 / 2016$ & Oct (dry to rainy) & 410 & 1.639 & 8.375 \\
& $\mathrm{~T} 3 / 2017$ & Aug (dry) & 99 & 990 & 366 \\
\cline { 2 - 6 } & T0/2016 & Mar (rainy to dry) & - & - & 54028 \\
& $\mathrm{~T} 1 / 2016$ & Jun (rainy to dry) & 1.801 & 5.404 & 59.432 \\
& $\mathrm{~T} 2 / 2016$ & Oct (dry to rainy) & 2.051 & 8.204 & 67.636 \\
& $\mathrm{~T} 3 / 2017$ & Aug (dry) & 494 & 4937 & 72.573 \\
\hline
\end{tabular}




\begin{tabular}{|c|c|c|c|c|c|c|}
\hline Location & Transect & Time & Month/Season & $\begin{array}{l}\text { Growth rate } \\
\left(\mathrm{cm}^{2} / \text { month }\right)\end{array}$ & $\begin{array}{c}\text { Growth } \\
\text { area }\left(\mathrm{cm}^{2}\right)\end{array}$ & $\begin{array}{c}\text { Total area } \\
\text { of cover } \\
\left(\mathrm{cm}^{2}\right)\end{array}$ \\
\hline Belanda & 1 & T0/2016 & Mar (rainy to dry) & - & - & 5.891 \\
\hline \multirow[t]{11}{*}{ Island } & & $\mathrm{T} 1 / 2016$ & Jun (rainy to dry) & n.a. & n.a. & n.a. \\
\hline & & $\mathrm{T} 2 / 2016$ & Oct (dry to rainy) & 129 & 906 & 6.797 \\
\hline & & $\mathrm{T} 3 / 2017$ & Aug (dry) & -585 & -5.849 & 948 \\
\hline & 2 & T0/2016 & Mar (rainy to dry) & - & - & 5.333 \\
\hline & & $\mathrm{T} 1 / 2016$ & Jun (rainy to dry) & 25 & 75 & 5.408 \\
\hline & & $\mathrm{T} 2 / 2016$ & Oct (dry to rainy) & 354 & 1.415 & 6.822 \\
\hline & & $\mathrm{T} 3 / 2017$ & Aug (dry) & 72 & 723 & 7.545 \\
\hline & Total & T0/2016 & Mar (rainy to dry) & - & - & 11.224 \\
\hline & & $\mathrm{T} 1 / 2016$ & Jun (rainy to dry) & 25 & 75 & 11.299 \\
\hline & & $\mathrm{T} 2 / 2016$ & Oct (dry to rainy) & 483 & 2.321 & 13.620 \\
\hline & & $\mathrm{T} 3 / 2017$ & Aug (dry) & -513 & -5127 & 8.492 \\
\hline
\end{tabular}

n.a. $=$ not available.

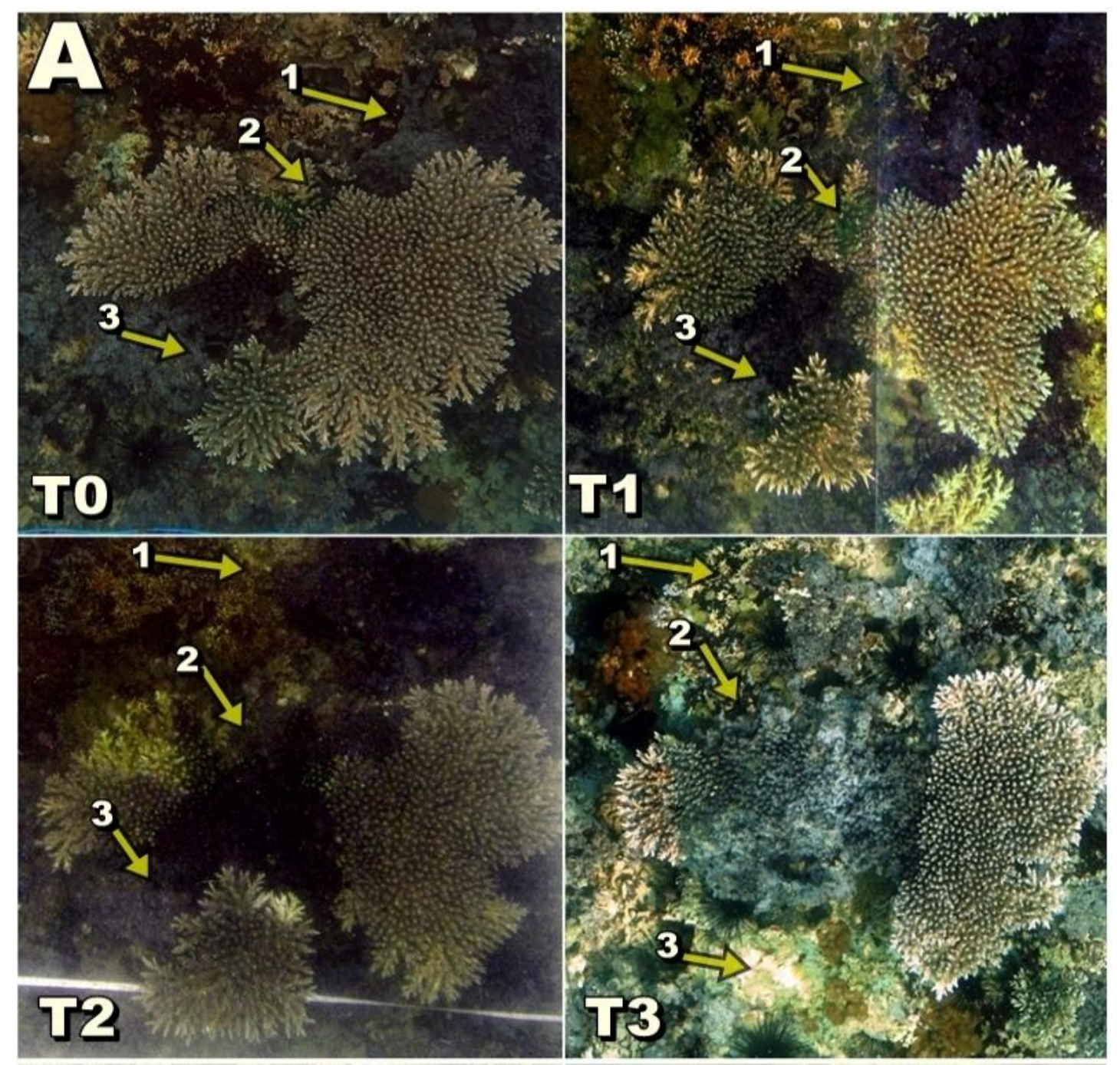

(a) 


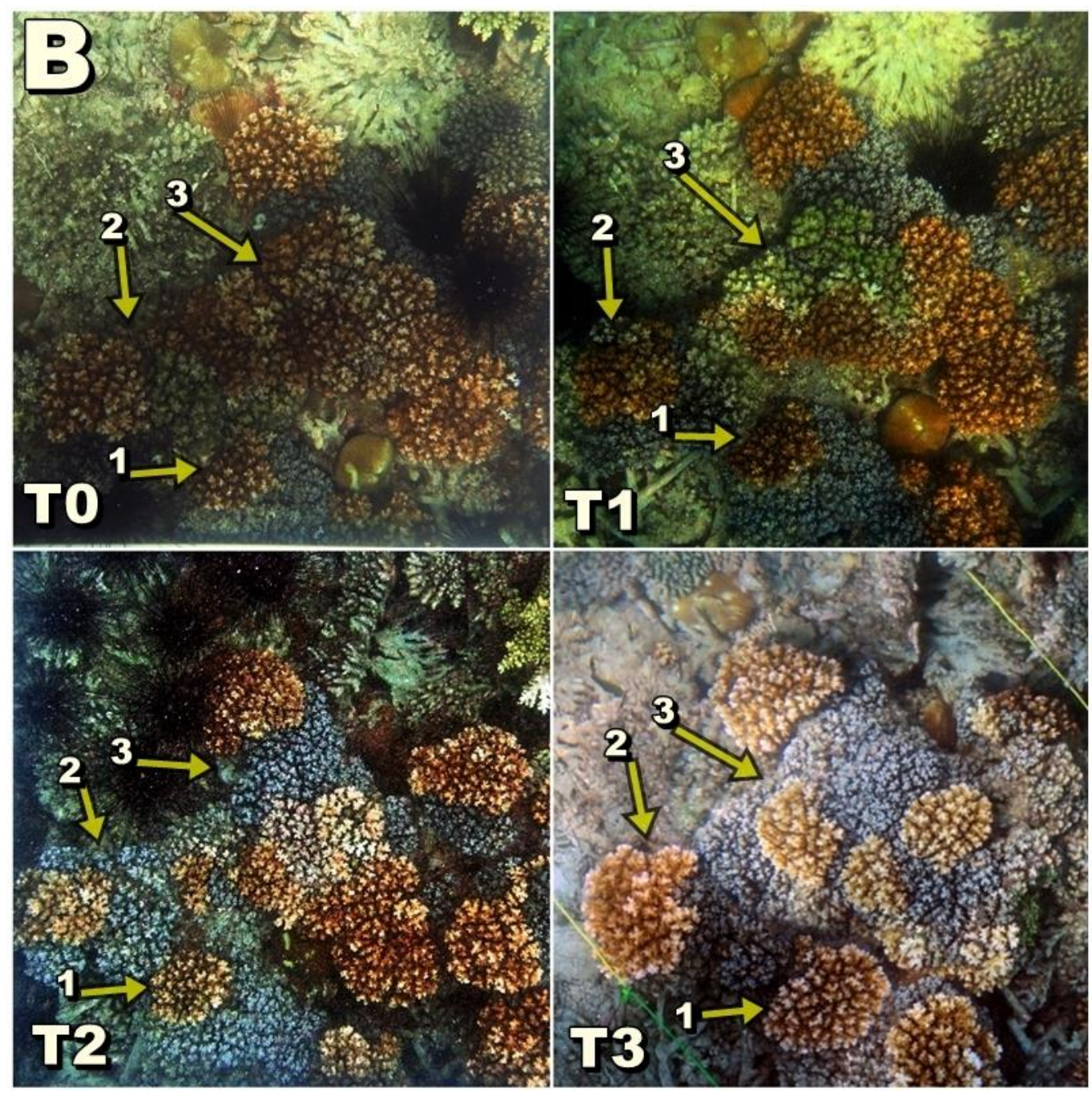

(b)

Figure 3. The movement pattern of the sponge within permanent transect at Dapur Island (a) and Belanda Island (b) on living coral substrate starts to exhibit a movement over 18 months in the observation.

black sponge cover has good spreading speed at the location of the Dapur Island with a hard substrate that has a density between the substrate very tightly (Figure 2.A) and within two months from the initial observation to the second observation an increase of $5.404 \mathrm{~cm}^{2}$. Belanda Island itself is found in the northern part which leads to open sea waters having the condition of the dominant substrate of coral reefs with large separate colonies, the movement was limited to black sponge outbreaks with the best growth area of only $2.321 \mathrm{~cm}^{2}$ over an eightmonth interval.
Its movement process in the research location of Dapur Island was dominated on the densely solid substrate in order to make easy its propagation to grow in the new areas (Figure 3.A), This location near the Mainland and in the Jakarta bay with murky enough waters as well as the basic substrate has the appropriate conditions of living coral growing massive and sub-massive. The movement pattern of this killer sponge is represented on the arrow number 1 , the corals signify a competition for a growing space between the living corals and the sponge $T$. hoshinota, sponge outbreaks it 
doesn't seem to reach the Acropora table reef that grew between the attacks of this black plague, to the time of this table coral building is destroyed starting there are separate parts that have been colonized by black sponges in arrow 2. While the conditions indicated by arrow 3, black sponges do not develop properly under the shade of table corals which are seen when the coral has been degraded.

Further, the observational location at Belanda Island, the sponge movement tended occurring on the living coral building forming a big colony, because this location is in the open waters so that the basic substrate conditions more dominated by living coral branching and has clear waters. In this station also points out the competition for space between the living coral and the sponge $T$. hoshinota is presented on arrow 1 and 2 which this time was won by the branchy coral Pocillopora from the early observation (T0) to the last observation (T3), is a coral competition against black sponges and algae for 3 arrows which only lasted for 3 months until the final observation. (T3) August 2017 and most have surrendered to the killer of the black sponge covered by $T$. hoshinota, also partially able to continue growth (Figure 3.B).

\subsubsection{Prevalence of Sponge T. hoshinota}

The prevalence of black encrusting cyanosponge outbreaks is shown in Figure 4. The prevalence in Belanda Island was significantly higher than in Dapur Island at each period of observation. This is the third time exposed to black sponge outbreaks in two different locations and the outbreak begins to decrease simultaneously in the fourth observation. This condition shows the existence of coral reefs that are able to survive and grow more persistently than the plague of black sponge killer T. hoshinota. However, this black sponge will be an epidemic that threatens the health of hard corals in this region, proven for 18 months of observation the existence of this sponge can survive in all weather conditions during the observation period.

The increase in prevalence at the two observation sites increased much higher in October 2016 (T2) by $14.21 \%$ from $8.70 \%$ on Dapur island and $33.11 \%$ from $28.97 \%$ on the Belanda island. This added to the death of coral reef colonies at the location of the outbreak. As the increase in prevalence results in Pocillopora branched coral genera experiencing the highest increase in exposure to death by $5.053 \mathrm{~cm} 2$ (T3) from $2.085 \mathrm{~cm} 2$ (T0) and the Acropora table

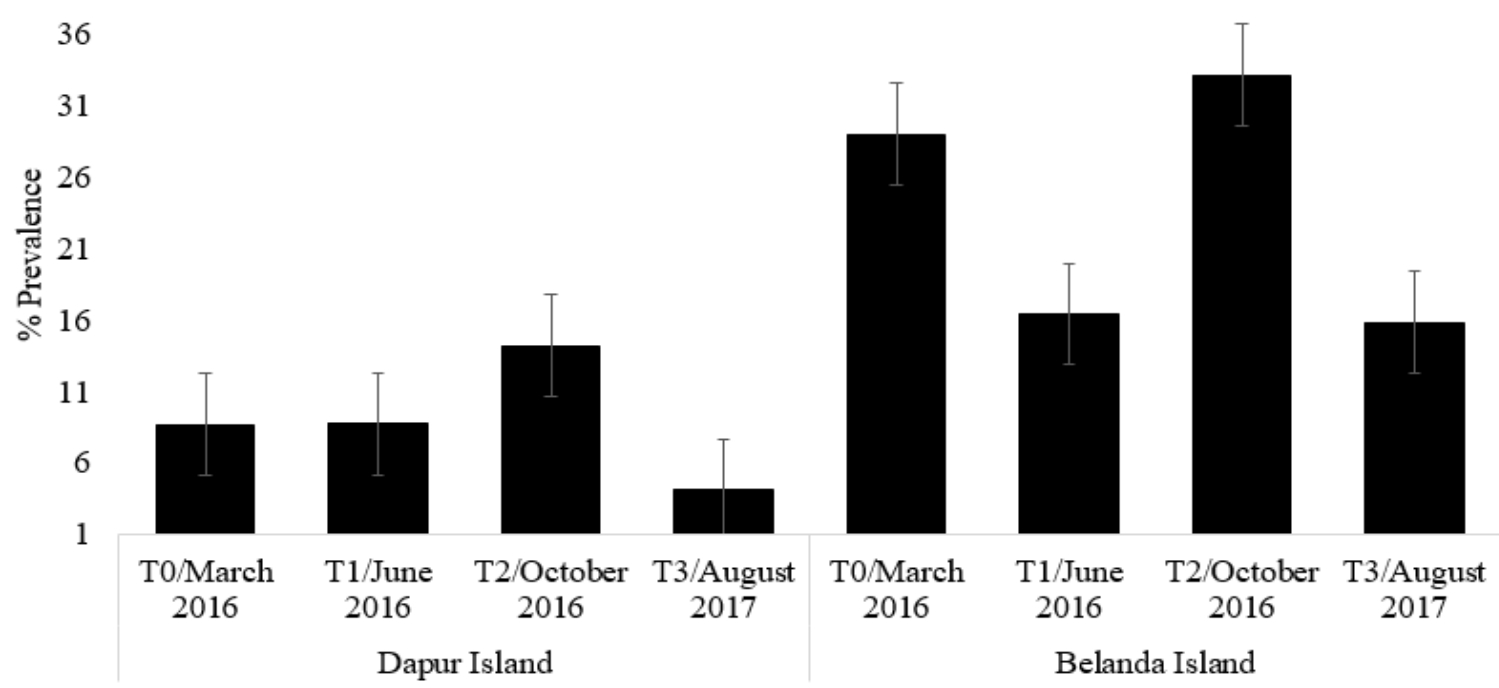

Figure 4. The prevalence (\%) causing by the sponge T. hoshinota at each study sites over period of observation. 
genera from $737 \mathrm{~cm} 2$ (T0) to $1.575 \mathrm{~cm} 2$ (T2) by observing T3 of this coral genera in part a large number of $T$. hoshinota outbreaks were destroyed by other factors

\subsection{Discussion}

\subsubsection{Coral Reefs Condition in the Surrounding Areas of $T$. hoshinota Outbreaks}

The coral reef is a threatened ecosystem icon that has been existing since 500 million years, but its ecological persistence still continuing is seemly doubt currently (Riegl et al., 2009). The lowering health condition of this ecosystem has various causes from physical factors such as an increasing number of components composing abiotic which is resulted by a very common happening activity like fishing in the coral reef area and eventually physical damages on the coral buildings. Then rising some coral inhabitant communities that are harmful and impact on the living coral cover condition as one of causing natural factors. However, many coral reef areas in around the world are getting threatened, mainly caused by overfishing, pollution, hurricane, global warming and increasing coral predators such as the Acanthaster planci (Teruya et al., 2001; Teruya et al., 2004). Our results obtained the amount of cover from the percentage of live coral on the two islands where this observation was in poor condition, only on the Belanda Island which had a higher live coral cover value than the Dapur Island. Showing the percent of live coral cover deteriorating from the results of previous studies. For Dapur island under good cover conditions and the Belanda island in a quite poor condition. (Cleary et al.,2008). Belanda Island which is one of the Core Zones should have a tendency to change the percentage of hard coral cover in a positive direction. The remote location of Belanda Island might lead to less intensive supervision resulting in a decrease in the percentage of closure (Fadila \& Idris, 2009). Sponge T. hoshinota is one of the natural impacts of coral reef damages currently. It makes solid substrates, including living corals, and often experiencing a huge plague which is able to cover a very large area that is resulted in the mass death of corals and inhabiting organisms of coral reefs (Rutzler \& Muzik 1993; Fujii et al., 2011).

Rising the plague which is harmful on the coral reef ecosystem in the Seribu Islands is able to magnify problems causing coral damages in this area. The identification based on the results of molecular DNA exhibits that the sponge species actually is $T$. hoshinota, a study conducting in the areas of Belanda Island and Dapur Island of Seribu Islands (Utami et al., 2018). Coral reefs become vulnerable due to one type of threat can be pushed towards ecological destruction if coupled with a second threat (Burke et al., 2012). Based on research conducted by Costantino et al. (2008) T. hoshinota sponges that grow rapidly in coral reef ecosystems, often causing death on corals, T. hoshinota sponges are the most important cause of coral reef destruction.

\subsubsection{Growth rate of Sponge \\ T. hoshinota}

Based on Table 3, namely the period from March 2016 to October 2016 means that for 7 months the observation resulted in a value of $2.051 \mathrm{~cm}^{2}$ for Dapur Area Island and $483 \mathrm{~cm}^{2}$ Belanda Islands area. The high growth rate of these sponges, around 1$2 \mathrm{~mm} /$ day, has caused the death of many corals, and steps to reduce or prevent further sponging of the crust have become a top priority (Tang et al., 2011). The fast growth rate of $T$. hoshinota is an asset that allows it to be a space competitor effective against scleractinian corals, a comparison of sponge growth rates with coral growth rates at least twice as high as Acropora branching corals 4-10 times higher (Elliott et al., 2015). Sponge $T$. hoshinota grows through lateral propagation, extending fine tendrils and crossing short slits to new substrates (Rutzler \& Muzik 1993). Expansion of this 
sponge was greatly aggressive in a span of four months from June 2016 to October 2016 during dry season. During the observation on the Maritus Island, sponge recruitment was low during the winter until the end of spring (Elliott et al., 2016). This sponge coats the living coral building to be death rapidly in tropical climate and it continues to explore other hard coral substrates in the adjacent areas. The first study report in Palk Bay evidences a fast coral death and increasingly is due to the invasion of $T$. hashinota in two years (Thinesh et al., 2017a). The shaded substrate under the shade of a table reef is not covered by the black sponge outbreak, and table corals grow well above the substrate with an uninterrupted black sponge outbreak. So that the destruction of the coral building was attacked because some of it was separated from the support of the table corals falling into the area of this black plague (Figure 3.A). An observation conducted in Tioman Island, Malaysia, point outs that the sponge $T$. hashinota possesses a preference on corals exposed to sunlight and it is able to grow excessively. Further, the shallow coral that has been exposed to this sponge plague is looked as though being killed, however, beneath the coral building still has a living part and far away from sunlight. This finding is looked consistently with the experiment results that shade can protect corals towards the sponge growth excessively (Soong et al., 2009: Hoeksema et al., 2014). There is a coral resistance from the Pocillopora genera capable of maintaining its growth around the attack of black sponges killing $T$. hoshinota on the location of the Belanda Island. Coral colonies of the types Acropora digitifera have retained the same boundaries with $T$. hoshinota for over a year without any progress or regression (Wang et al., 2012).

\subsubsection{Spatial and Temporal Variation of Sponge T. hoshinota}

Almost all components of hard bottom substrates not covering by sands are able to be used as the growing media of the sponge $T$. hoshinota, for species and life forms of exposing this sponge plague depend on the structures of coral colonies in each location. The tighter the hard substrates and side by side to the living corals, the easier this sponge broadens to the new areas. The preference of finalizing a test implies that the sponge $T$. hoshinota might not directly attack the healthy living corals, but settles on other hard substrates close to the corals (Hsu et al., 2013). The location of a Dapur Island near the Jakarta Bay area in the southern part of the Seribu Islands was found in more black sponges $T$. hoshinota from the northern region, the Belanda Island. The competition for space between the sponge T. hoshinota and the living corals was very fierce. The coral reefs with an unhealthy condition and commonly in pale color or looked different in a colony, the sponge is able to reign a part of the coral building. Looked a wide difference of the measured sponge plague in the two research locations emphases that the different bottom characteristics affect highly the distribution pattern of this sponge, and these locations are no more than $6 \mathrm{~m}$ depth. The four different found locations of T. hoshinota are varied each other in a benthic community structure. The sponge is found in two sites highly, unstable, and low living corals, algae, coral ruins, and sand (Esther et al., 2015).

From a distance of three months the black sponge outbreak shows its nervousness increasing dramatically when entering the high dry season in both different locations, this condition is erratic when the coverage area of black sponges at the end of the fourth observation spans nine months decreases and enters different years, where the results of recording several images show a good increase in the growth of living coral reefs from sponge growth. $T$. hoshinota reproductive season occurs during the summer. (Hirose \& Murakami, 2011; Nozawa et al., 2016). Also, some transect 
locations on the kitchen island have increased coral cover covering the sponge outbreak. Research conducted by Shi et al. (2012) they observed that coral had previously been covered with black crust sponges. It was difficult to assess whether there would be an appearance of algae. We found corals which were the growth media for black sponges physically damaged (fractures) and their surfaces with turfs algae growing slowly on the location of the Belanda Island. However, the Terpios outbreak sometimes shows setbacks (negative growth) and can even be overgrown by some coral organisms (Montipora and Porites) or red calcareous algae (Plucer, 1987; Wang et al., 2012). Although there was a decrease in the extent of the outbreak during this period of observation it did not cause the outbreak to disappear completely. Obviously, these sponges are very persistent on coral reefs, and once they have invaded a new area, they will remain there permanently (Reimer et al., 2011; Esther et al., 2015).

The location of the distance of the Dapur and Belanda islands is so far away, the basic characteristics of the islands are certainly different. Dapur islands that are still affected by the bad condition of Jakarta Bay and the rather turbid waters of the Belanda island make the dominant coral that grows is the massive and sub-species of Porites. The T. hoshinota outbreak in Palk Bay is likely to be higher due to the impact of anthropogenic activities (Thinesh et al., 2017b). Likewise, the results of this study show the appearance of many $T$. hoshinota sponges on Dapur Island. Turbid waters that cause not all types of rock can grow well, without distinguishing the type, found that rock corals that have massive forms of growth have a high tolerance to environmental changes (Giyanto \& Sukarno, 1997; Tuti et al., 2010). So that the density between coral colonies is better than the Belanda islands which are predominantly branching corals of Acropora and
Pocilopora species. This is the positive and negative value that exists on each island against the spread of black sponge outbreaks that are often seen creeping in on the surface of solid substrates. That the direction of overgrowth by a sponge may be associated with the level of compactness coral, indicating that health status corals can also be a determining factor in Terpios infection. (Averts, 2000; Wang et al., 2012). The condition of coral reef ecosystems in the Thousand Islands tends to resemble interislands, except for a few islands that are located near or located in Jakarta Bay (Untung Jawa island) (Estradivari et al., 2009). Dapur Island near the southern part of Untung Jawa.

\subsubsection{Prevalence of Sponge T. hoshinota}

Dapur Island has a lower prevalence of black sponges for corals from Belanda Island. In Dapur Island, the exposure of small coral substrates that live here and black sponges are found on the basic substrate of rocks and coral reefs. Conversely, Belanda Island was observed with a high prevalence value because of the high percentage of live coral substrates. So that this black sponge outbreak predominantly moves on the coral reef substrate. After this outbreak of black disease, it can last up to a decade occupying the substrate and preventing the emergence of young coral recruitment (Liao et al., 2007). The Belanda Island which has a high prevalence rate at the beginning of the observation, from the second observation occurs because the outbreak data calculation is incomplete on the observation transect 1 . but basically, there was an increase shown by the same location on transect 2 also at the same time on different island locations from the total area cover of the black sponge outbreak (Table 3) and the photo recording portion of growth T0 and T1 (Figure 3). At the end of the observation of the black sponge outbreak rate that killed corals in both locations declined, this was like being 
challenged by coral reefs and some areas of the outbreak were also covered by soft coral colonies. In most cases, these two competitors can alternately lose and gain tissue and space to grow during 15-month intervals. (Chornesky, 1989; Lisanne, 2000). Almost similar to what was found by Rocktim et al (2020) scenario at stations 5 and 6 after the $T$. hoshinota outbreak attacked the reef and killed the reef death here by sponsoring $T$. hoshinota sponsors and grass algae took over. Highlighting the long-term symptoms of the $T$. hoshinota outbreak should be seen as a threat to coral disease and might be one of the most important disturbances affecting coral reefs (Liao et al., 2007). Prevalence values dropped at some time observations did not cover up the black outbreak will stop developing, and the outbreak disappeared from its area of existence.

All observing areas, there are two coral categories becoming victims of the sponge $T$. hoshinota outbreak ferocity namely the Acropora and branchy nonAcropora like Porites and Pocillopora, and Porites and non-branchy Fungia. During a biodiversity survey recently in Faafu Atoll, Maladewa, the sponge $T$. hoshinota was observed growing excessively in the living corals such as Porites, Acropora, Cyphastrea, Montipora and coral colonies of Pavona in 13 different locations in a range depth of 7 to $24 \mathrm{~m}$ (Montano et al., 2015). Based on genera, there are 2 corals, namely Acropora and Pocillopora which experienced the most striking increase in mortality when the prevalence increased. According to Tinnesh et al (2017) on the Palk Bay reef, Southeast coast of India. From 1930 colonies examined, 25.4\% ( $\mathrm{n}=$ 492) were effects shaded by $T$. hoshinota sponges during the study period, where the percentage has increased from the initial amount of $1.3 \%(n=25)$.

\section{CONCLUSIONS}

This study reveals the sponge Terpios hoshinota able to overgrown almost all hard substrate buildings and densities between solid substrates determine the fast or slow deployment process in one area of the coral reef ecosystem. The highest growth level was observed in Dapur Island (the closest site to Jakarta) during transitional season from rainy season to dry season. While the lowest growth rate of sponge was observed during transitional season from the dry season to rainy season. In general, prevalence percentage was higher in Belanda Island than in Dapur Island. This study showed a persistence of $T$. hoshinota proliferation.

\section{ACKNOWLEDGMENT}

This research is supported by an International Collaboration Program (Program Kerja sama Luar Negeri, KLN) with a research theme 'Counteracting Loss of Biotechnological Resources Ecosystem Functions Caused by Potentially Climate Change-Driven Sponge Invasions into Indonesian Coral Reefs funded by Ristekdikti, also the Scientific Diving Laboratory, and thank for permission delivering by Kepulauan Seribu National Park, Jakarta to conduct this research in both core protecting zone and common zone.

\section{REFERENCES}

Averts, L.A.M. 2000. Dynamics behind standoff interactions in three reef sponge species and the coral Montastrea cavernosa. Marine Ecology, 21(3-4): 191-204. https://doi.org/10.1046/j.14390485.2000.00685.x

Burke, L., K. Reytar, M. Spalding, \& A. Perry. 2012. Reefs at Risk Revisited in the Coral Triangle. World Resources Institute (WRI). in: 
Menengok Kembali Terumbu Karang yang Terancam di Segitiga Terumbu Karang (TERANGI). Indonesia. 90 p. https://wriindonesia.org/id/publication/meneng ok-kembali-terumbu-karang-yangterancam-di-segitiga-terumbu-karang

Chornesky, E.A. 1989. Repeated reversals during spatial competition between corals. Ecology, 70(4): 843-855. https://doi.org/10.2307/1941353

Cleary, D.F.R., L. DeVantier, Giyanto, L. Vail, P. Manto, N. de Voogd, P.G. Rachello-Dolmen, Y. Tuti, A. Budiyanto, J. Wolstenholme, B.W. Hoeksema, \& Suharsono. 2008. Relating variation in species composition to environmental variables: a multi-taxon study in an Indonesian coral reef complex. Aquat. Sci., 70: 419-431. https://doi.org/10.1007/s00027-0088077-2

Costantino, V., E. Fattorusso, C. Imperatore, A. Mangoni, \& R. Teta. 2008. Terpioside from the Marine Sponge Terpios sp., the First Glycosphingolipid Having anLFucofuranose Unit. European J. of Organic Chemistry, (12): 2130-2134. https://doi.org/10.1002/ejoc.2007012 20

De Voogd, N.J., D.F.R. Cleary, \& F. Dekker. 2013. The coral-killing sponge Terpios hoshinota invades Indonesia. Coral Reefs, 32: 755. https://doi.org/10.1007/s00338-0131030-4

Diaz, M.C. \& K. Rutzler. 2001. Sponges: an essential component of Caribbean coral reefs. Bulletin of Marine Science, Sci, 69(2): 535-546. https://repository.si.edu/bitstream/ha ndle/10088/7877/iz_Diaz_Ruetzler_2 001.pdf

Edinger, E.N., J. Jompa, G.V. Limmon, W. Wijadmoko, \& M.J. Risk. 1998. Reef degradation and coral biodiversity in indonesia: effects of land-based pollution, destructive fishing practices and changes ovar time. Marine Pollution Bulletin, 36(8): 617-630.

https://doi.org/10.1016/S0025326X(98)00047-2

Elliott, J., M. Petterson, N. Summers, C. Miternique, E. Montocchio, \& E. Vitry. 2016. How does the proliferation of the coral-killing sponge Terpios hoshinota affect benthic community structure on coral reefs?. Coral Reefs, 35(3): 10831095.

https://doi.org/10.1007/s00338-0161434-z

Elliott, J., M. Petterson, E. Vitry, N. Summers, \& C. Miternique. 2015. Morphological plasticity allows coral to actively overgrow the aggressive sponge Terpios hoshinota (Mauritius, Southwestern Indian Ocean). Marine Biodiversity, 46: 489-493. https://doi.org/10.1007/s12526-0150370-4

English, S., C. Wilkinson, \& V. Baker. 1997. Survey Manual for Tropical Marine Resources (2nd Edition). Australia: Australian Institute of Marine Science. Australia. 390 p.

Esther, V.D.E., B.W. Hoeksema, \& N.J. De Voogd. 2015. Abundance and genetic variation of the coral-killing cyanobacteriosponge Terpios hoshinota in the Spermonde Archipelago, SW Sulawesi, Indonesia. $J$. of the Marine Biological Association of the United Kingdom, 96(2): 453-463. https://doi.org/10.1017/S0025315415 00034X

Estradivari, Idris, \& M. Syahrir. 2009. Study of Structure of Hard Coral Communities to Thousands of 2005 \& 2007. Foundation TERANGI, Jakarta. 102: 29-39 pp. 
Fadila \& Idris. 2009. Comparison of biennial percentage of coral cover in the Thousand Islands (2003, 2005 and 2007), Foundation TERANGI, Jakarta. 102: 23-28 pp.

Fonnegra, C.A., L. Castellanos, S. Zea, C. Duque, J. Rodri'guez, \& C. Jim'enez. 2008. Clionapyrrolidine A-A Metabolite from the Encrusting and Excavating Sponge Cliona tenuis that Kills Coral Tissue upon Contact. $J$. Chem Ecol., 34(12): 1565-1574. https://doi.org/10.1007/s10886-0089565-5

Fujii, T., S. Keshavmurthy, W. Zhou, E. Hirose, C.A. Chen, \& J.D. Reimer. 2011. Coral-killing cyanobacteriosponge (Terpios hoshinota) on the Great Barrier Reef. Coral Reefs, 30: 483. https://doi.org/10.1007/s00338011-0734-6

Giyanto. 2013. Underwater photo transect method for assessing the condition of coral reefs. Oseana, XXXVIII(1): 47 61.

http://oseanografi.lipi.go.id/dokumen /os_xxxviii_1_2013-5.pdf

Giyanto \& Soekarno. 1997. Comparison of coral reef communities at two depths and four different zones on the Thousand Islands, Jakarta. Oceanology and Limnology Bulletin in Indonesia. 30: 33-51 pp.

Gomez, E.D., P.M. Alino, H.T. Yap \& W.Y. Licuanan. 1994. A review of the status of Philipine reefs. Marine Polution Bulletin, 29(1-3): 62-68.

https://doi.org/10.1016/0025326X(94)90427-8

Hadi, T.A., M. Abrar, Giyanto, B. Prayudha, O. Johan, A. Budiyanto, A.R. Dzumalek, L.A. Alifatri, S. Sulha, \& Suharsono. 2020. The Status of Indonesian Coral Reefs 2019. Center for Oceanographic Research (LIPI). $89 \mathrm{p}$.

Hirose, E. \& A. Murakami. 2011. Microscopic anatomy and pigment characterization of coral-encrusting black sponge with cyanobacterial symbiont, Terpios hoshinota. Zoological Science, 28: 199-205. https://doi.org/10.2108/zsj.28.199

Hoeksema, B.W., Z. Waheed, \& N.J. de Voogd. 2014. Partial mortality in corals overgrown by the sponge Terpios hoshinota at Tioman Island, Peninsular Malaysia (South China Sea). Bulletin of Marine Science, 90(4): 989-990. http://doi.org/10.5343/bms.2014.104 7

Hsu, C.M., J.T. Wang, \& Chen. 2013. Larval release and rapid settlement of the coral-killing sponge, Terpios hoshinota, at Green Island. Taiwan. Marine Biodiversity, 43: 259-260. https://doi.org/10.1007/s12526-0130176-1

Johan, O. 2010. Cause, impact and management of coral disease on coral reefs ecosystem. Media Akuakultur, Indonesian. 5(2): 144-152. https://doi.org/10.15578/ma.5.2.2010 .144-152

Liao, M.H., S.L. Tang, C.H. Hsu, K.C. Wen, W. Hanry, W.M. Chen, J.T. Wang, P.J. Meng, W.H. Twan, C.K. Lu, C.F. Dai, K. Soong, \& C.A. Chen. 2007. The black disease of reefbuilding corals at Green Island, Taiwan-Outbreak of a Cyanobacteriosponge, Terpios hoshinota (Suberitidae; Hadromerida). Zoological studies, 46(4): 520. http://zoolstud.sinica.edu.tw/Journals 146.4/520.pdf

Lisanne, A.M.A. 2000. Dynamics behind standoff interactions in three reef sponge species and the coral Montastraea cavernosa. Marine Ecology, 21: 191-204. http://doi.org/10.1046/j.14390485.2000.00685.x 
Madduppa, H., P.J. Schupp, M.R. Faisal, M.Y. Sastria, \& C. Thoms. 2017. Persistent outbreaks of the "black disease" sponge Terpios hoshinota in Indonesian coral reefs. Marine Biodiversity, 47: 149-151. https://doi.org/10.1007/s12526-0150426-5

Montano, S., W.H. Chou, C.A. Chen, P. Galli, \& J.D. Reimer. 2015. First record of the coral-killing sponge Terpios hoshinota in the Maldives and Indian Ocean. Bulletin of Marine Science. 91: 97-98. http://doi.org/10.5343/bms.2014.105 4

Mujiyani., D. Hidayanti, L. Rachmawati, Tonisoetopo, G.B. Aji, \& R. Cahyadi. 2001. Small island management and community participation, case study in the Thousand Islands, DKI Jakarta. Population Research Center of the Indonesian Institute of Sciences (PPK-LIPI 2001, Jakarta. 128 p. http://file.pksdmo.lipi.go.id/id023a1e59-2650_307.pdf

Nozawa, Y., Y.S. Huang, \& E. Hirose. 2016. Seasonality and lunar periodicity in the sexual reproduction of the coralkilling sponge, Terpios hoshinota. Coral Reefs, 35: 1071-1081. https://doi.org/10.1007/s00338-0161417-0

Pawlik, J.R., L. Steindler, T.P. Henkel, S. Beer, \& M. Ilan. 2007. Chemical warfare on coral reefs: sponge metabolites differentially affect coral symbiosis in situ. Limnol Oceanography, 52(2): 907-911. https://doi.org/10.4319/lo.2007.52.2. 0907

Plucer, R.G. 1987. The effect of substratum on the growth of Terpios, an encrusting sponge which kills corals. Coral Reefs, 5: 197-200. https://doi.org/10.1007/BF00300963
Porter, J.W. \& N.M. Targett. 1988. Allelochemical interactions between sponges and corals. Biological Bulletin, 175(2): 230-239. https://doi.org/10.2307/1541563

Raj, K.D., M.S. Bharath, G. Mathews, G.S. Aeby, \& J.K.P. Edward. 2018. Coralkilling sponge Terpios hoshinota invades the corals of Gulf of Mannar, Southeast India. Current Science. 114(5): 1117-1119. https://doi.org/10.18520/cs\%2Fv114 \%2Fi05\%2F1117-1119

Raymundo, L.J., C.S. Couch, \& C.D. Harvell. 2008. Coral disease handbook: guidelines for assessment, monitoring and managment. Coral Reef Targeted Research and Capacity Building for Management Program. The University of Queensland. Australia. 124 p.

Reimer, J.D., M. Mizuyama, M. Nakano, T. Fujii, \& E. Hirose. 2011. Current status of the distribution of the coralencrusting cyanobacteriosponge Terpios hoshinota in southern Japan. Galaxea, J. of Coral Reef Studies, 13: 35-44. https://doi.org/10.3755/galaxea.13.35

Rossi, G., S. Montori, C. Cerrano, \& B. Calcinai. 2015. The coral killing sponge Chalinula nematifera (Porifera: Haplosclerida) along the eastern coast of Sulawesi Island (Indonesia). Italian J. Zoology, 82(1): 143-148. https://doi.org/10.1080/11250003.20 14.994046

Roctim, R.D., C.R. Sreeraj, M. Gopi, K.R. Abhilash, S.V. Deepak, R. Purvaja, \& R. Ramesh. 2019. Incursion of the killer sponge Terpios hoshinota Rützler \& Muzik, 1993 on the coral reefs of the Lakshadweep archipelago, Arabian Sea. J. of Threatened Taxa, 12(14): 1700917013. 
https://doi.org/10.11609/jott.5790.12. 14.17009-17013

Rutzler, K. \& K.M. Muzik. 1993. Terpios hoshinota, a new cyanobacteriosponge threatening Pacific reefs. Scientia Marina, 57(4): 395-403.

https://repository.si.edu/bitstream/ha ndle/10088/7882/iz_Ruetzler_Muzik _1993.pdf

Shi, Q., G.H. Liu, H.Q. Yan, \& H.L. Zhang. 2012. Black Disease (Terpios hoshinota): A probable cause for the rapid coral mortality at the northern reef of Yongxing Island in the South China Sea. AMBIO. 41(5): 446-455. https://doi.org/10.1007/s13280-0110245-22019

Soong, K., S.L. Yang, \& C.A. Chen. 2009. A novel dispersal mechanism of a coral-threatening sponge, Terpios hoshinota (Suberitidae, Porifera). Zoological Studies. 48(5): 596. http://zoolstud.sinica.edu.tw/Journals /48.5/596.html

Subhan, B., H. Madduppa, D. Arafat, \& D. Soedharma. 2014. Can coral transplantation improve coral reef ecosystems. J. Risalah Kebijakan Pertanian dan Lingkungan, 1(3): 159-164.

https://doi.org/10.20957/jkebijakan.v $1 \mathrm{i} 3.10292$

Subhan, B., F. Rahmawati, D. Arafat, \& N.A. Bayu. 2011. Coral Health Condition of Family Fungiidae on Pramuka Island, Seribu Island. J. Teknologi Perikanan dan Kelautan, 2(1): 41-50.

https://doi.org/10.24319/jtpk.2.41-50

Sutanto, D. 2014. Six islands in Jakarta were lost due to abrasion and sand theft. Merdeka.com. 22:39.

Tang, S.N., M.J. Hong, M.H. Liao, W.N. Jane, P.W. Chiang, C.B. Chen, \& C.A. Chen. 2011. Bacteria associated with an encrusting sponge (Terpios hoshinota) and the corals partially covered by the sponge. Environmental Microbiology, 13(5): 1179-1191. https://doi.org/10.1111/j.14622920.2010.02418.x

Teruya, T., S. Nakagawa, T. Koyama, H. Arimoto, M. Kita, \& D. Uemura. 2004. Nakiterpiosin and nakiterpiosinone, novel cytotoxic Cnor-D-homosteroids from the Okinawan sponge Terpios hoshinota. Tetrahedron, 60: 6989-6993. https://doi.org/10.1016/j.tet.2003.08. 083

Teruya, T., K. Suenaga, T. Koyama, Y. Nakano, \& D.J. Uemura. 2001. Arachidonic acid and $\alpha$-linolenic acid, feeding attractants for the crown-of-thorns sea star Acanthaster planci, from the sea urchin Toxopneustes pileolus. J. of Experimental Marine Biology and Ecology, 266: 123-134. https://doi.org/10.1016/S00220981(01)00337-9

Thinesh, T., R. Meenatchi, R. Pasiyappazham, J. Polpass, S. Muthamizh, K. Seghal, \& S. Joseph. 2017a. Short-term in situ shading effectively mitigates linear progression of coral-killing sponge Terpios hoshinota, Plos One, 12(10): e0187004.

https://doi.org/10.1371/journal.pone. 0182365

Thinesh, T., G. Mathews, K.D. Raj, \& J.K.P. Edward. 2017b. Outbreaks of Acropora white syndrome and Terpios sponge overgrowth combined with coralmortality in Palk Bay, southeast coast of India. Dis. Aquat. Org, (126): 63-70. https://doi.org/10.3354/dao03155

Tuti, H.Y., Suharsono, Giyanto, \& R. Manogar. 2010. Effect of turbidity on the coral reef ecosystem in the Thousand Islands. Final report of the LIPI researcher and engineer 
incentive program in 2010. P20, LIPI. Jakarta. 37 p.

Utami, R.T., N.P. Zamani, \& H. Madduppa. 2018. Molecular identification, abundance and distribution of the coral-killing sponge Terpios hoshinota in Bengkulu and Seribu Islands, Indonesia. Biodiversitas J. of Biological Diversity, 19(3): 22382246.

https://doi.org/10.13057/biodiv/d190 632

Wang, J.T., Y.Y. Chen, P.J. Meng, Y.H. Sune, C.M. Hsu, K.Y. Wei, \& C.A. Chen. 2012. Diverse Interactions between Corals and the Coral-Killing Sponge, Terpios hoshinota (Suberitidae: Hadromerida). Zoological Studies, 51(2): 150-159. https://www.researchgate.net/publica tion/259865910

Wang, J.T., C.M. Hsu, C.Y. Kuo, P.J. Meng, S.J. Kao, \& C.A. Chen. 2015. Physiological out performance at the Morphologically-Transformed Edge of the Cyanobacteriosponge Terpios hoshinota (Suberitidae: Hadromerida) when Confronting
Opponent Corals. Plos ONE, 10(6): e0131509.

https://doi.org/10.1371/journal.pone. 0131509

Wilkinson, C. 2004. Status of coral reefs of the world:2004. global coral reef monitoring network. Australian, (2): $368 \mathrm{p}$.

Wilkinson, C. 2008. Status of Coral Reefs of The World: 2008. Australian Institute of Marine Science. Australia. 296 p.

Yamaguchi, M. 1986. Introduction to the study of coral reefs 4 Coral-reef sponges (1) Sponges as destroyers of reef-building corals. Japanese. 8: 88$92 \mathrm{pp}$.

Zamani, N.P. \& H. Madduppa. 2011. A standard criteria for assessing the health of coral reefs: implication for management and conservation. $J$. of Indonesia Coral Reefs, 1(2): 137146.

https://www.researchgate.net/publica tion/262260292

Received : 25 June 2020

Reviewed : 13 July 2020

Accepted : 14 December 2020 